\title{
Global action on the urgency of climate change Academic and research libraries' contributions
}

A the time of this writing, Australia's bushfires are raging, Jakarta is experiencing massive flooding, and waves of earthquakes are devastating islands in the Caribbean. Hundreds of thousands of people and living creatures are being torn from their homes. The mind reels at the intensity and scale of these climate changeinduced disasters. At the same time, the world's leading decision makers seem to finally be waking up to the emergency. For instance, the European Union (EU) just announced 1 trillion euro plan to support the European Green Deal, including a mechanism designed to help regions (e.g., coal-dependent Poland) that would be most disrupted economically by the transition to cleaner industries. Moreover, with the aim to make Europe the world's first carbon-neutral continent by 2050, the EU pledges a just transition, that is to "leave no one behind."

How do academic libraries fit into the complicated, unfolding story of our planet's future? Examples of best practice for thriving and regenerating include providing climate change resources and education, advocating for open access information, modeling green values, creating programs that center on respectful dialogue and deliberation, ${ }^{2}$ offering open space for reflection, ${ }^{3}$ and serving as resiliency hubs for disaster response, includ- ing medical supplies, warming/cooling stations, and electronic device charging. ${ }^{4}$

Abundant examples of the green library movement are threaded through professional library journals and books, on social media, and at library association conferences. Many point to the 1989 formation of the Task Force on the Environment (TFOE) as the beginning of the movement. TFOE was created in the spirit of the 20th Anniversary of Earth Day (1990) under the ALA's Social Responsibilities Round Table. The group spurred the association's first environmental program at its 1991 annual conference. ${ }^{5}$ Launched in 1994, the Green Library Journal: Environmental Topics in the Information World signaled a turning point in scholarly publishing. It is now the well-respected Electronic Green Journal. ${ }^{6}$ Monika Antonelli and Mark McCullough's 2012 co-edited book Greening Libraries includes examples from several academic

\footnotetext{
Madeleine Charney is research services librarian at University of Massachusetts-Amherst, email: mcharney@library.umass.edu, and Petra Hauke is a visiting teacher at the Berlin School for Library and Information Science at Humboldt-Universität zu Berlin, Germany, email: petra.hauke@hu-berlin.de. They are information officer and convener of IFLA's Special Interest Group Environment Sustainability and Libraries (ENSULIB), respectively.
}

(c) 2020 Madeleine Charney and Petra Hauke 
libraries and Mandy Henk's 2014 book, Ecology, Economy, Equity: The Path to a CarbonNeutral Library, considered the "first book to seriously examine the future of libraries in a climate reality-based context," 7 offers practical steps for rethinking library operations and services in light of climate change. More recently, The Sustainable Library's Cookbook, coauthored in 2019 by Ray Pun and Gary L. Shaffer, offers academic libraries a menu of ideas for programming, curriculum, and sustainable thinking processes. ${ }^{8}$

Looking at broader systems of academic library contributions to the climate change movement, the Association for the Advancement of Sustainability in Higher Education (AASHE) STARS reporting and tracking system now includes contributions from the campus library. ${ }^{9}$ A campus receives credits if it offers ongoing library support for sustainability research and learning (e.g., research guides, e-learning objects focused on sustainability), limits paper and ink consumption (e.g., restricting free printing and/or mandating doubled-sided printing in libraries), has an institutional repository with free access on public computers (consistent with the Budapest Open Access Initiative, an international effort to make research articles in all academic fields freely available on the Internet), provides an open access article processing charge fund for employees, and offers open access journal hosting services at no or minimal cost.

\section{Examples of sustainability strategies in academic libraries}

The following academic libraries, recently awarded "runner-up" status for the IFLA Green Library Award are examples of academic libraries addressing climate change issues. ${ }^{10}$ They demonstrate a wide range of possibilities to position themselves as responsible motors for sustainability. ${ }^{11}$

Green Strategies-The Chinese University of Hong Kong Library

The Chinese University of Hong Kong (CUHK) spotlights socially responsibility as it plays a leadership role within the CUHK's Green Governance Framework. The CUHK Library formulated, developed, and implemented a green strategy in the context of the university's approach to sustainability. ${ }^{12}$ The library's strategic plan includes a vision statement saying the library wishes to be recognized for "engaging with our students, faculty and the wider university community to design and deliver user-centered, sustainable services and spaces." In addition to operations like green library services, a "Green Office Programme," energy saving strategies, waste management, and green-building efforts, one of the library's successful initiatives raises awareness of sustainability issues among library staff through a rooftop organic vegetable garden installed on the new library extension roof. The library offered training and support to more than 40 staff volunteers who have become organic gardeners. Even after 18 months, they have no difficulty filling vacancies with new gardeners when staff leave.

Applying for the Good of All-The University College Cork Library, Ireland

The University College Cork, like all public-sector organizations in Ireland, is obliged to improve energy efficiency. ${ }^{13}$ As the library was one of the biggest users of electricity it was chosen to pilot a "Saver Saves" scheme to ensure that any monetary savings made from improving efficiency would remain within the library, to be reinvested in future environmental projects. A "Green Team" created a template to be rolled out across campus. The team determined how best to address issues in the library while communicating with all stakeholders. They work on monitoring and evaluating the progress of the sustainability project and constantly seek new ways to keep the project moving.

The initiative also offers practical solutions to waste problems and produces a major impact that can be scaled and shared 
by libraries around the world. The library has developed a road map for other organizations to follow. An additional feature of the project is its strong and consistent communications strategy that keeps all stakeholders updated and involved. Finally, the library has made visible "green" changes to their organization, such as real changes in the people's behavior. More than 10,000 students signed a sustainability campaign "Love our Library" to support the changes.

"Let's Go Green"-The National and University Library, Zagreb, Croatia

Green and sustainable libraries, a fastemerging consciousness in librarianship, has motivated the National and University Library (NUL) to educate their users, and to promote and popularize sustainable development, organic food production, environmentalism, alternative energy, green technology, and architectural innovations with earth-friendly materials. Consequently, NUL in Zagreb organized the "Let's Go Green Festival" in 2017.14 This event presented the latest academic research in sustainability issues through lectures and talks and invited green businesses to present their products and services to a wider community. The festival promoted sustainable agriculture and food science, green technologies, green energy, and building design and materials.

The success inspired NUL to organize the "First International Green Library Conference Let's Go Green" the following year in cooperation with the Working Group for Green Libraries of the Croatian Library Association. ${ }^{15}$ The conference was an opportunity to encounter the latest trends in this new field and exchange experiences and examples of best practices. Scientists, experts, and activists of international renown in the field of green libraries presented inspiring talks.

\section{Conclusion}

According to the Intergovernmental Panel on Climate Change, we have less than 11 years to pull back from the cliff of catastrophic global climate change. In that time, unprecedented changes in all aspects of society need to happen, including a reduction of carbon dioxide emissions by at least 50\%. Start the conversation with your co-workers and library patrons, reach out to stakeholders, conduct a formal sustainability assessment of your library, form a sustainability committee, and take action. Sign the Libraries4Future's "Declaration of Principles." ${ }^{16}$ The possibilities for librarians to boost the world's "collective immune system" ${ }^{17}$ are limitless. When each of us takes steps where we work, and share our vision and actions, change happens for the good of all.

We need to act on the words of Greta Thunberg, the Swedish teenager fiercely urging the world's leading decision makers to wake up. "I want you to act as you would in a crisis. I want you to act as if our house is on fire," she implored, with piercing eyes at her audience at the 2019 World Economic Forum in Davos, "Because it is." 18

\section{Selected resources}

American Library Association: Sustainability and Libraries, Green Libraries, https://libguides.ala.org/SustainableLibraries/Green (accessed January 7, 2020).

Charney, Madeleine: "A Sustainability Librarian's Manifesto: Your "Take Action" Checklist," Going Green@ Your Library, https:// greeningyourlibrary.wordpress.com /tag/checklist/ (accessed January 7, 2020).

Green Libraries: Sustainable Library Buildings, A Guide to Resources and Trends in Sustainable Library Building Design, www.designinglibraries.org. uk/?PageID=44 (accessed January 7, 2020).

Green Library Network Germany, "Bibliography," https://www.netzwerkgruene-bibliothek.de/en/bibliografie/ (accessed January 7, 2020). 
Petra Hauke, Karen Latimer, and Klaus Ulrich Werner (eds.), The Green Library $=$ Die Grüne Bibliothek $=$ The Challenge of Environmental Sustainability (Berlin/ Boston: De Gruyter, 2013), https://www. ibi.hu-berlin.de/de/studium/studprojekte/ buchidee/bi12 (accessed January 7, 2020).

Petra Hauke, Madeleine Charney, and Harri Sahavirta (eds.), Going Green: Implementing Sustainable Strategies in Libraries Around the World; Buildings, Management, Programmes and Services (Berlin/ Boston: De Gruyter, 2018).

\section{Notes}

1. "EU lays out 1 trillion-euro plan to support Green Deal," https://apnews.com 15d4db8ffda58f03f090a04c35f0a2dc8 (accessed January 17, 2020).

2. "Libraries Promoting Reflective Dialogue," https://librariesdialogue.wordpress. com/about-this-book/ (accessed January 16, 2020).

3. "A space apart: College libraries contemplate meditation rooms," American $\mathrm{Li}$ braries Magazine, January 2, 2018, https:// americanlibrariesmagazine.org/2018/01/02 /library-meditation-rooms-space-apart/ (accessed January 16, 2020).

4. "Communities Responding the Extreme Weather: Resilience Hubs," https://www. climatecrew.org/resilience_hubs (accessed January 16, 2020).

5. "Growing our vision together: Forming a sustainability community within the American Library Association," https://www. tandfonline.com/doi/abs/10.1080/15487733. 2015.11908147 (accessed January 16, 2020).

6. "Electronic Green Journal," https:// escholarship.org/uc/uclalib_egj (accessed January 16, 2020).

7. "Ecology, Economy, Equity: The Path to a Carbon-Neutral Library," https://www. alastore.ala.org/content/ecology-economy -equity-path-carbon-neutral-library (accessed January 16, 2020).

8. The Sustainable Library's Cookbook, https://www.acrl.ala.org/acrlinsider/archives/18495 (accessed January 16, 2020)
9. Association for the Advancement of Sustainability in Higher Education, STARS Technical Manual 2.2, https://stars.aashe. org/wp-content/uploads/2019/01/STARS-2.2 -Technical-Manual-early-release-5.pdf (accessed January 16, 2020).

10. IFLA Green Library Award, https:// www.ifla.org/node/10159 (accessed January 7, 2020).

11. IFLA, "Sustainability is Libraries' Business: Libraries and Sustainable Development," https://www.ifla.org/DE/publications /node/81763 (accessed January 7, 2020).

12. Louise Jones and Winky Wong, "More than just a green building: developing green strategies at the Chinese University of Hong Kong Library," Library Management 37 (6-7) (2016): 373-84.

13. IFLA Green Library Award 2019: Ireland, Cork, University College Cork Library, "Love Our Library," https://www.ifla. org/node/92213 (accessed January 7, 2020).

14. IFLA Green Library Award 2018: Project Submission: "Green Festival- Lets Go Green,” https://www.ifla.org /node/60935?og=479 (accessed January 7, 2020).

15. Let's Go Green: The First International Green Library Conference, Zagreb, Briuni, Croatia, November 8-10, 2018, http:// letsgogreen.nsk.hr/announcement/first -announcement/ (accessed January 7, 2020).

16. Libraries4Future: Declaration, https://libraries4future.org/en/petition/ (accessed January 7, 2020).

17. Our collective im mune system: Trauma and curiosity, State of Emergence, https://poddtoppen.se/podcast/ 1474393287 /state-of-emergence/010-thomas-hubl-our -collective-immune-system-trauma-and -curiosity (accessed January 16, 2020).

18. "'Our house is on fire': Greta Thunberg, 16, urges leaders to act on climate," The Guardian, January 25, 2019, https://www. theguardian.com/environment/2019/jan/25 /our-house-is-on-fire-greta-thunberg16-urges -leaders-to-act-on-climate (accessed January 14, 2020). 